\title{
ECMO: a lifesaving modality in ARDS during puerperium
}

\author{
Sunil K. Juneja', Pooja Tandon ${ }^{1 *}$, Vivek Gupta ${ }^{2}$, Gurpreet S. Wander ${ }^{2}$, Rajesh Mahajan ${ }^{3}$, \\ Akashdeep Singh ${ }^{4}$, Reetika Aggarwal ${ }^{1}$, Monika Narang ${ }^{1}$, Suhasini Raina ${ }^{1}$
}

\begin{abstract}
${ }^{1}$ Department of Obstetrics and Gynecology, Dayanand Medical College and Hospital, Ludhiana, Punjab, India ${ }^{2}$ Department of Cardiology, HDHI, Ludhiana, Punjab, India

${ }^{3}$ Department of Medicine, ${ }^{4}$ Department of Pulmonology, Dayanand Medical College and Hospital, Ludhiana, Punjab, India
\end{abstract}

Received: 16 February 2018

Revised: 06 July 2018

Accepted: 06 September 2018

\author{
*Correspondence: \\ Dr. Pooja Tandon, \\ E-mail: drpoojatandon77@gmail.com
}

Copyright: (c) the author(s), publisher and licensee Medip Academy. This is an open-access article distributed under the terms of the Creative Commons Attribution Non-Commercial License, which permits unrestricted non-commercial use, distribution, and reproduction in any medium, provided the original work is properly cited.

\begin{abstract}
Acute respiratory distress syndrome (ARDS) is an uncommon condition encountered in pregnancy. The incidence of ARDS in pregnancy has been reported to be 1 in 6229 deliveries with mortality rates to range from $24 \%$ to $39 \%$ in pregnant patients. An essential component in management of ARDS involves good communication between the obstetrics team and critical care specialist and a fundamental understanding of mechanical ventilatory support. In critically ill patients where both cardiorespiratory support is required, Extracorporeal Membrane Oxygenation (ECMO) can be used to help maintain the vital functions. ECMO is a temporary cardio respiratory or respiratory support in critically ill patients who are unresponsive to conventional management. In present case a young female with post-partum ARDS was successfully managed with extra corporeal membrane oxygenation (ECMO).
\end{abstract}

Keywords: ARDS, ECMO, Puerperium

\section{INTRODUCTION}

Acute respiratory distress syndrome (ARDS) is an uncommon condition encountered in pregnancy. The causes of ARDS associated with nonobstetric causes include sepsis, aspiration pneumonitis, influenza pneumonia, blood transfusions, and trauma whereas obstetric causes include amniotic fluid embolism, preeclampsia, septic abortion, and retained products of conception. The incidence of ARDS in pregnancy has been reported to be 1 in 6229 deliveries for an incidence of 17 patients per 100000 with mortality rates to range from $24 \%$ to $39 \%$ in pregnant patients. ${ }^{1}$ An essential component in management of ARDS involves good communication between the obstetrics team and critical care specialist and a fundamental understanding of mechanical ventilatory support. ${ }^{2}$ In critically ill patients where both cardiorespiratory support is required, Extracorporeal Membrane Oxygenation (ECMO) is used to help maintain the vital functions. ECMO is a temporary cardio respiratory or respiratory support in critically ill patients who are unresponsive to conventional management. It is a highly specialized form of ICU management where blood from the person's body is withdrawn through a widebore canula in a major vein (the right or left common femoral vein) and artificially the carbon dioxide is removed and red blood cells are oxygenated and then the blood is returned back to the right or left femoral artery. ${ }^{3}$ Authors here by present a case of young female with post-partum ARDS successfully managed with extra corporeal membrane oxygenation (ECMO). 


\section{CASE REPORT}

A 25 years old, primigravida at 37 weeks gestation presented in our emergency department with complaints of pain lower abdomen and loss of fetal movements for 8 hrs. Apart from being hypothyroid for 3 years she had an uneventful antenatal period. She underwent Lower segment Cesarean section due to fetal distress. The routine laboratory investigations were normal. Two days after the uneventful caesarean section she developed cough and fever and got examined by a physician.

Table 1: Serial investigations.

\begin{tabular}{|c|c|c|c|c|c|c|c|c|c|c|c|c|c|c|c|}
\hline Dates/ Test & $12 / 8$ & $13 / 8$ & $14 / 8$ & $15 / 8$ & $16 / 8$ & $17 / 8$ & $18 / 8$ & $19 / 8$ & $20 / 8$ & $21 / 8$ & $22 / 8$ & $23 / 8$ & $24 / 8$ & $25 / 8$ & $26 / 8$ \\
\hline $\mathrm{Hb}(\mathrm{g} / \mathrm{dl})$ & 9.8 & 10.1 & 10.1 & 9.6 & 9.1 & 9.1 & 8.5 & 9.1 & 8.5 & 9.5 & 9.5 & & 11.7 & & 11.9 \\
\hline $\operatorname{PCV}(\%)$ & 29.3 & 30.4 & 30.0 & 28.6 & 27.5 & 27.8 & 26.1 & 28.0 & 26.1 & 28.9 & 29.3 & & 35.7 & & 35.8 \\
\hline $\begin{array}{l}\text { WBC } \\
\text { (Count/cmm) }\end{array}$ & 5.4 & 5.2 & 5.5 & 6.4 & 8.4 & 9.7 & 9.3 & 8.6 & 10.1 & 12.0 & 12.3 & & 14.0 & & 13.1 \\
\hline Urea (mg/dl) & 19 & 15 & 13 & 12 & 16 & 16 & 34 & 41 & 34 & 34 & 43 & & & 37 & \\
\hline $\begin{array}{l}\text { Creatinine } \\
(\mathrm{mg} / \mathrm{dl})\end{array}$ & 0.52 & 0.4 & 0.4 & 0.38 & 0.45 & 0.4 & 0.40 & 0.37 & 0.52 & 0.45 & 0.44 & & & 0.67 & \\
\hline Blood glucose & 173 & 94 & 100 & 124 & 120 & 120 & 110 & 119 & 98 & 108 & 142 & 158 & 88 & 90 & \\
\hline PHOS (mg/dl) & 2.2 & & & & 2.4 & & & 4.0 & & & 3.9 & & & & \\
\hline SGOT & 49 & & 88 & & 74 & & 30 & & & & 25 & & & & \\
\hline SGPT & 13 & & 21 & & 28 & & 22 & & & & 20 & & & & \\
\hline \multicolumn{16}{|l|}{ AST (U/L) } \\
\hline \multicolumn{16}{|l|}{ ALT (U/62L) } \\
\hline TBIL (mg/dl) & 0.30 & & 0.31 & & 0.5 & & 0.48 & & & & 0.94 & & & & \\
\hline DBIL (mg/dl) & 0.19 & & 0.1 & & 0.11 & & 0.19 & & & & 0.22 & & & & \\
\hline $\mathrm{TP}(\mathrm{g} / \mathrm{dl})$ & 4.7 & & 5.0 & & 5.2 & & 5.3 & & & & 5.8 & & & & \\
\hline ALB (g/dl) & 2.4 & & 2.49 & & 2.49 & & 2.4 & 2.8 & & & 2.68 & & & & \\
\hline CAL (mg/dl) & 7.2 & & & & 7.4 & & & 8.2 & & & 8.6 & & & & \\
\hline ALP (U/L) & 109 & & 122 & & 121 & & 127 & & & & 117 & & & & \\
\hline MG (mg/dl) & 1.81 & & & & 2.08 & & & 2.06 & & & 2.06 & & & & \\
\hline \multicolumn{16}{|l|}{$\mathrm{A} / \mathrm{G}$} \\
\hline $\mathrm{Na}^{+}(\mathrm{mmol} / \mathrm{l})$ & 140 & 138 & 137 & 137 & 143 & 144 & 138 & 144 & 137 & 135 & 136 & & & 136 & \\
\hline $\mathrm{K}^{+}(\mathrm{mmol} / \mathrm{l})$ & 3.43 & 3.82 & 3.69 & 3.76 & 3.24 & 3.85 & 4.05 & 4.80 & 4.42 & 4.47 & 3.97 & & & 4.97 & \\
\hline $\mathrm{Cl}(\mathrm{mmol} / \mathrm{l})$ & 108 & 107 & 103 & 102 & 106 & 104 & 98 & 92 & 100 & 99 & 101 & & & 93 & \\
\hline $\mathrm{TSH}(\mu \mathrm{UL} / \mathrm{ml})$ & 0.23 & & & & & & 1.25 & & & & & & & & \\
\hline PLT $10^{\wedge} 3 \mu \mathrm{L}$ & 166 & 157 & 162 & 156 & 169 & 164 & 143 & 146 & 195 & 237 & 302 & & 403 & & 394 \\
\hline PT/INR & $\begin{array}{l}12.5 / \\
1.15\end{array}$ & $\begin{array}{l}11.4 / \\
1.04\end{array}$ & $\begin{array}{l}11.7 / \\
1.06\end{array}$ & $\begin{array}{l}11.3 / \\
1.03\end{array}$ & $\begin{array}{l}11.6 / \\
1.06\end{array}$ & $\begin{array}{l}12.1 / \\
1.10\end{array}$ & & & & & & & & & \\
\hline PTTK / ratio & $\begin{array}{l}78.3 / \\
2.53\end{array}$ & $\begin{array}{l}42.6 / \\
1.54\end{array}$ & $\begin{array}{l}42.9 / \\
1.55\end{array}$ & $\begin{array}{l}40.5 / \\
1.47\end{array}$ & $\begin{array}{l}39.3 / \\
1.42\end{array}$ & $\begin{array}{l}50.0 / \\
1.81\end{array}$ & $\begin{array}{l}12.8 / \\
1.16\end{array}$ & $\begin{array}{l}45.0 / \\
1.63\end{array}$ & & & & & & & \\
\hline
\end{tabular}

Table 2: Procalcitonin levels (marker of sepsis).

\begin{tabular}{|llll|ll|} 
Date & $12 / 8$ & $14 / 8$ & $15 / 8$ & $17 / 8$ & $18 / 8$ \\
\hline Result (ng/ml) & 0.10 & 0.09 & 0.10 & 0.09 & 0.07
\end{tabular}

X-ray Chest PA view was done which showed small opacities bilaterally. On subsequent day she developed difficulty in breathing and was not maintaining oxygen saturation $(\mathrm{SPO} 2=80 \%)$.

Initially she was managed with oxygen and NIV support and later intubated and mechanically ventilated for 16 hours. Inspite of high ventilator support she was not able to maintain oxygen saturation thus was diagnosed as ARDS.

The chest $X$ ray showed in homogenous haziness in right lower zone and left mid zone along with paracardiac shadows. Echocardiogram showed normal systolic function with $\mathrm{EF}=60 \%$.

Veno-venous ECMO was started after securing right femoral artery and right femoral vein with appropriate size cannula and adequate flow was maintained with centrifugal pump.

Inotropic support was gradually reduced and kept to minimum. Appropriate oxygenation was maintained through adequate pump flow.

The haemodynamic, metabolic and coagulation parameters were monitored strictly. Daily X-ray chest was done. Appropriate nutrition, physiotherapy and other supportive therapies were continued. Once oxygenation started improving the veno-venous ECMO support and mechanical ventilation was gradually weaned off. 
Table 3: Investigations.

\begin{tabular}{|c|c|c|}
\hline Investigation & Date & Results \\
\hline $\begin{array}{l}\text { Blood and } \\
\text { body fluid } \\
\text { culture }\end{array}$ & $\begin{array}{l}15.08 .2017 \\
22.08 .2017\end{array}$ & $\begin{array}{l}\text { Organisms isolated, no } \\
\text { growth. } \\
\text { Organisms isolated, no } \\
\text { growth. }\end{array}$ \\
\hline $\begin{array}{l}\text { Smear for } \\
\text { gram staining }\end{array}$ & 03.08 .2017 & $\begin{array}{l}\text { Gram positive cocci in } \\
\text { pairs (few), Pus cells (few) }\end{array}$ \\
\hline $\begin{array}{l}\text { Anti-HIV } \\
\text { (CMIA) }\end{array}$ & 12.08.2017 & 0.18 Non-reactive \\
\hline $\begin{array}{l}\text { Triage BNP } \\
\text { per strip }\end{array}$ & & $32 \mathrm{pg} / \mathrm{ml}$ \\
\hline Echo & 22.08.2017 & $\begin{array}{l}\mathrm{EF}=60 \% \text { Normal LV size } \\
\text { and systolic function }\end{array}$ \\
\hline PBF & 26.08 .2017 & $\begin{array}{l}\text { Normocytic normochromic } \\
\text { RBC picture, leucocytosis } \\
\text { with neutrophilia seen. No } \\
\text { toxic granules seen. Platelets } \\
\text { are adequate in the smear } \\
\text { examination. }\end{array}$ \\
\hline USG chest & 13.08.2017 & $\begin{array}{l}\text { Mild amount of pleural } \\
\text { effusion along posterolateral } \\
\text { chest wall bilaterally with } \\
\text { underlying collapse/ } \\
\text { consolidation }\end{array}$ \\
\hline $\begin{array}{l}\text { USG } \\
\text { abdomen }\end{array}$ & 10.08 .2017 & $\begin{array}{l}\text { Liver, GB, Pancreas, Spleen } \\
\text { normal, B/L Kidneys: norme } \\
\text { echogenity, corticomedullar: } \\
\text { junction maintained, UB } \\
\text { empty, Uterus: postpartum } \\
\text { no Ascitis, minimal } \\
\text { pleural effusion in left side } \\
\text { noted }\end{array}$ \\
\hline Chest X ray & 12.08.2017 & $\begin{array}{l}\text { In homogenous haziness } \\
\text { seen in right lower zone } \\
\text { along para cardiac shadows. } \\
\text { In homogenous haziness } \\
\text { seen in left mid zone. } \\
\text { Domes of diaphragm, } \\
\text { bony thoracic cage grossly } \\
\text { normal }\end{array}$ \\
\hline
\end{tabular}

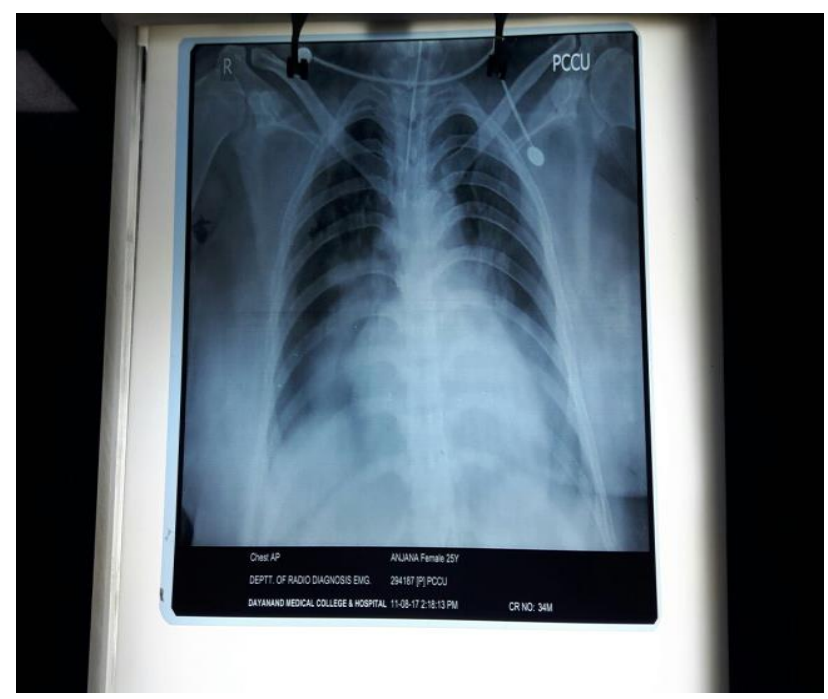

Figure 1: Chest $\mathrm{X}$ ray post-operative day 3.

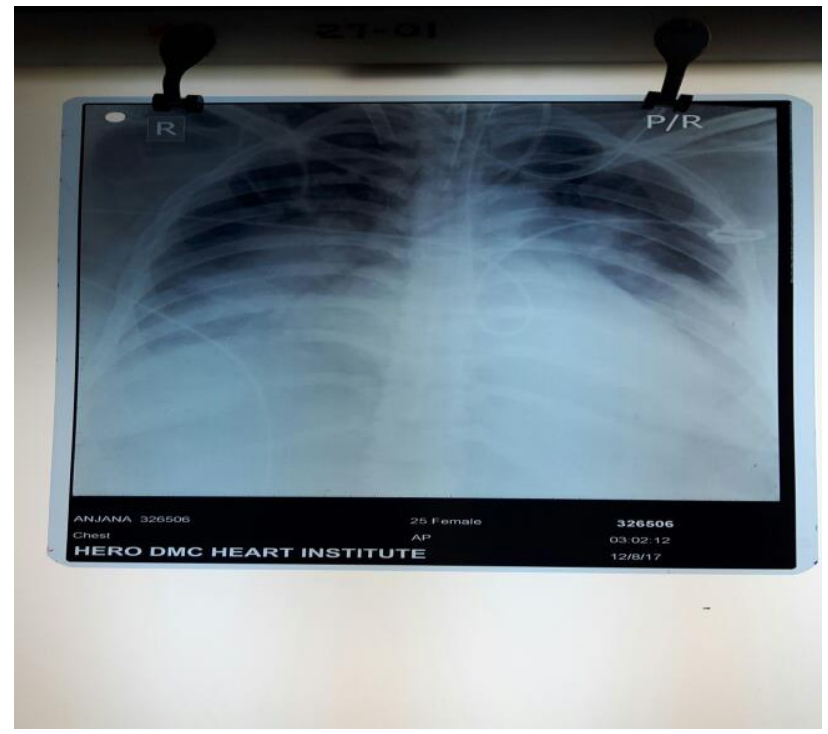

Figure 2: Chest X ray post-operative day 4.

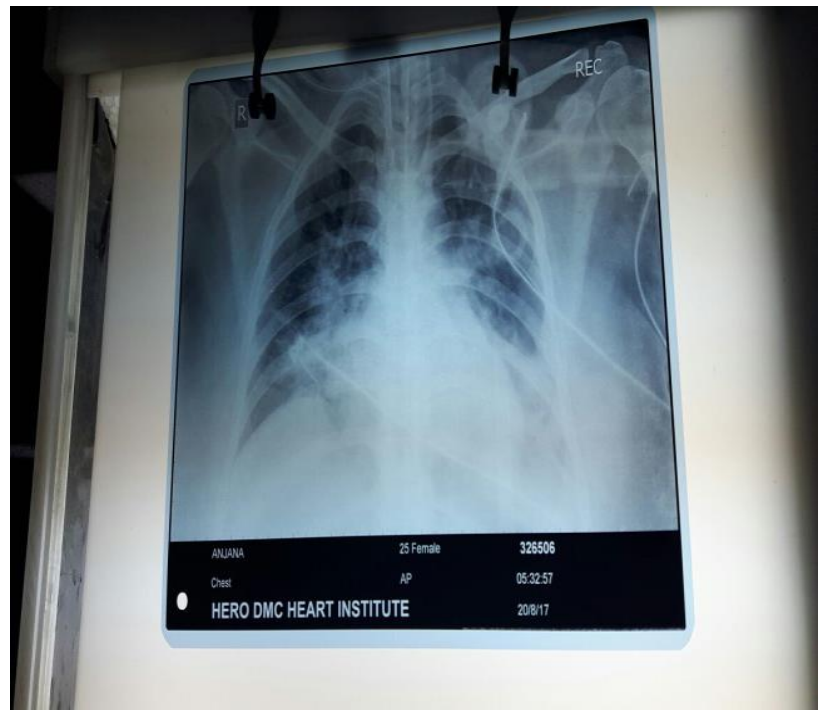

Figure 3: Chest X ray post-operative day 13.

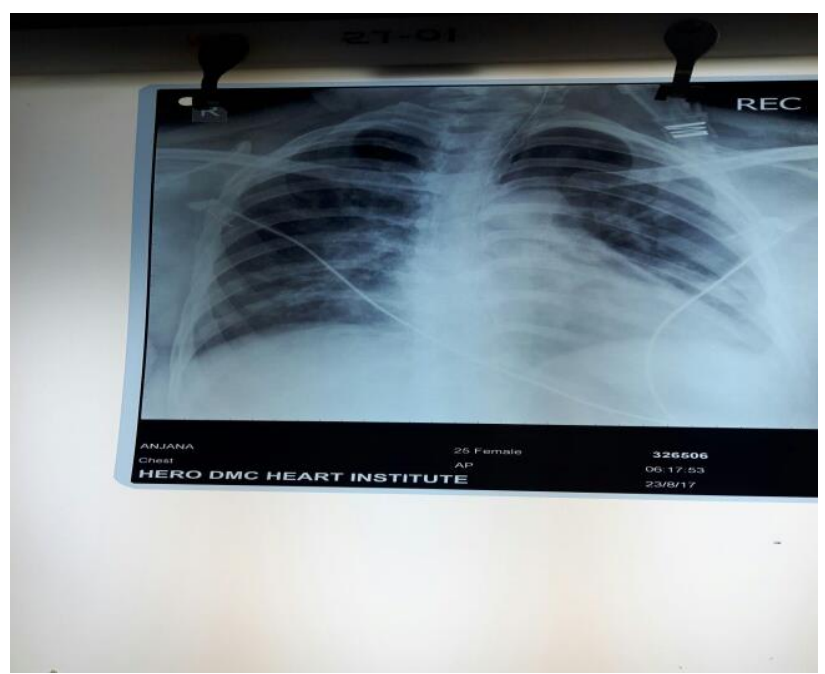

Figure 4: Chest $X$ ray post-operative day 17. 


\section{DISCUSSION}

A pregnant patient is at risk of developing acute lung injury from pregnancy-associated complications as well as other conditions. Acute respiratory distress syndrome (ARDS) is not uncommon in pregnancy and is a leading cause of maternal death. ${ }^{1,2,4}$ The pregnant state may predispose to the development ARDS by a number of mechanisms, including the increased circulating blood volume, the reduced serum albumin level, a possible upregulation of components of the acute inflammatory response and increased capillary leak. ${ }^{5}$

There are few differences in the management of the pregnant patient who has ARDS compared with one who is not pregnant. Survival from ARDS appears to be as good as or better than that in the general population, likely because of these patients' young age, lack of comorbidity, and the reversibility of many of the predisposing conditions, with an anticipated $40 \%$ to $75 \%$ survival rate. ${ }^{1,3,6}$

The available modalities for the management of ARDS include noninvasive and invasive methods. Noninvasive methods like high flow oxygenation, i.v. fluids and antibiotics are the primary modality of management. However, when patients show difficulty in maintaining saturation invasive methods like mechanical ventilation are opted. Invasive modalities include Mechanical Ventilation, Airway pressure release ventilation, Positive end-expiratory pressure, prone position, fluid management, corticosteroids, nitric oxide, surfactant therapy and extracorporeal membrane oxygenation (ECMO). The mechanical ventilation has its own complications like barotrauma, pneumonitis, nosocomial infection. ${ }^{7-9}$ Therefore the present case is important as it highlights the importance of extracorporeal membrane oxygenation (ECMO) in the management of ARDS especially in post-partum period. ${ }^{10-12}$

\section{CONCLUSION}

Seeing the above case authors can say that ARDS can be a potential life-threatening complication in pregnancy and post-partum patients due to increased predisposition. ECMO can be a lifesaving tool in these cases. It is important to shift the patient to a tertiary care centre having ECMO facilities.

Funding: No funding sources Conflict of interest: None declared Ethical approval: Not required

\section{REFERENCES}

1. Yildirim F, Kara I, Türk M, Kat I. Acute Respiratory Distress Syndrome due to Sepsis in Pregnancy. J Clin Respir Dis Care. 2016;2(114).

2. Ware LB, Matthay MA. The acute respiratory distress syndrome. N Engl J Med. 2000;342:1334-9.

3. Madershahian N, Nagib R, Wippermann J, Strauch J, Wahlers T. A simple technique of distal limb perfusion during prolonged femoro-femoral cannulation. J Card Surg. 2006;21(2):168-9.

4. Bernard GR, Artigas A, Brigham KL, Carlet J, Falke $\mathrm{K}$, Hudson L, et al. The American-European Consensus Conference on ARDS. Definitions, mechanisms, relevant outcomes, and clinical trial coordination. Am J Resp Crit Care Med. 1994;149(3):818-24.

5. Ashbaugh D, Bigelow DB, Petty T, Levine B. Acute respiratory distress in adults. Lancet. 1967;290(7511):319-23.

6. Schwartz MI, Albert RK. "Imitators" of the ARDS: Implications for diagnosis and treatment. Chest 2004; 125:1530-5.

7. Smith JL, Thomas F, Orme Jr JF, Clemmer TP. Adult respiratory distress syndrome during pregnancy and immediately postpartum. Western $\mathbf{J}$ Med. 1990;153(5):508-10.

8. Proceedings of the $4^{\text {th }}$ Margaux conference on critical illness: acute lung injury. Understanding the mechanisms of injury and repair. Sintra, Portugal, November 13-17, 2002. Crit Care Med. 2003;31(Suppl): S183-342.

9. Catanzarite V, Willms D, Wong D, Landers C, Cousins L, Schrimmer D. Acute respiratory distress syndrome in pregnancy and the puerperium: causes, courses, and outcomes. Obstet Gynecol. 2001;97(5):760-4.

10. Luce JM. Acute lung injury and the acute respiratory distress syndrome. Crit Care Med. 1998; 26:369-76.

11. Catanzarite VA, Willms D. Adult respiratory distress syndrome in pregnancy: report of three cases and review of the literature. Obstet Gynecol Surv. 1997;52:381-92.

12. Mabie WC, Barton JR, Sibai BM. Adult respiratory distress syndrome in pregnancy. Am J Obstet Gynecol. 1992;167(4):950-7.

Cite this article as: Juneja SK, Tandon P, Gupta V, Wander GS, Mahajan R, Singh A, et al. ECMO: a lifesaving modality in ARDS during puerperium. Int J Reprod Contracept Obstet Gynecol 2018;7:4285-8. 